\title{
The current situation and developing countermeasures of Chinese railway refrigerated transportation
}

\author{
Ping Guo 1, a , Dawei Cui ${ }^{2, b}$ \\ ${ }^{1}$ College of Economics \&Management, Weifang University, Weifang, China \\ ${ }^{2}$ College of Economics \&Management, Weifang University, Weifang, China \\ aguoping436@163.com, bwfxycdw@163.com
}

\begin{abstract}
Keywords: perishable goods. railway. refrigerated transportation. joint transportation.
Abstract. The paper explains the overview of domestic and international refrigerated transportation. It also points out some problems existing in the railway refrigerated transportation of China. The article discusses the reform of refrigerated transportation organization, the development of advanced refrigeration transportation equipment, and developing joint transportation of perishable goods, adjusting freight rate and strengthening cooperation between the railways and the logistics park. Finally, the development strategies are addressed.
\end{abstract}

\section{Introduction}

Along with the development of economy in our country, the people's living standard has been raised, and the developing trend of the consumption ideas will be diversification and speediness. There is big increase in demand for refrigerated transport. "Small batch, multi-variety, high refreshment" have become the leading direction of refrigerated transport. As railway refrigerated transport is an important part of perishable code chain, due to the problems existed in the business characteristics, operation characteristic and the management system, the market share of railway in the refrigerated freight market is reducing continuously. With the implementation of railway construction plan, refrigerated transport will have a very good opportunity.

\section{Overview of domestic and international refrigerated transport}

Refrigerated transport rates in Europe and America and other developed countries are $80 \%-90 \%$, Russian and Eastern European countries are 50\%, while the developing countries are only 10\% -20\%. At present perishable goods has been transported in our country about 40,000 tons per year, which rail, road and water, air transport rate are $25 \%, 15 \%, 1 \%, 0.1 \%$, respectively. And all the other adopt the railway box cars and the flatcars without refrigerated circulation facilities.

In developed countries, the market share of railway refrigerated transport is small. The perishable goods mainly used the large refrigerated trailer are transported by highway, the transport distance of up to $4500-5500 \mathrm{~km}$. The transport speed is twice than the railway. For example, in 1984, to speed up delivery of goods, reduce operating costs, the marshalling yard had been abolished in Japan. From here we see that railway refrigerated transport with adaptation to long-distance direct transportation and rapid transportation is promising. Mechanically refrigerated cars and mechanical refrigerated containers can do this. In addition, the mechanically refrigerated cars in the United States and Europe are the single-style refrigerator cars, and the group-style cars are in Russian. Because some features such as too large batches, unaccustomed to small quantities of perishable goods and etc., Russia is now also made to expand the proportion of single-style vehicle decision.

\section{The problems of railway refrigerated transport in China}

Along with the development of economy in our country, the people's living standard has been raised, and the developing trend of the consumption ideas will be diversification and speediness. There is big 
increase in demand for refrigerated transport. "Small batch, multi-variety, high refreshment" have become the leading direction of refrigerated transport. As railway refrigerated transport is an important part of perishable code chain, due to the problems existed in the business characteristics, operation characteristic and the management system, the market share of railway in the refrigerated freight market is reducing continuously. With the implementation of railway construction plan, refrigerated transport will have a very good opportunity.

\section{Poor equipment in condition and lower utilization rate}

Railway refrigerated lorry is increased nearly 3000 from 1995 to 2005, but the volume was about 500 million tons moving down-bound. Since the icing branch of whole railway system is not enough, especially icing-making capacity of railway re-icing point in Beijing-Guangzhou, Beijing-Shanghai, Longhai, and Zhejiang-Jiangxi railway line, etc. can not meet the transport demand, thus leading to an annual limit of hot season in the ice refrigerated lorry and the limited refrigerated trucks cannot obtain the full use. And the railway has not yet to solve transport facilities of refrigerated container origin, transfer and power supply problems. So the refrigerated container can not be good to play a role in the railway.

Whole railway system has nearly 8,000 refrigerated cars, where 2292 mechanically refrigerated cars, on average every car loading 11.6 times and turnover time is about 31.5 days per year. Meanwhile, more than 5,000 ice refrigerated cars without a special department have poor condition and lower utilization rate. The five-cars mechanical refrigerator with large capacity does not meet the transport demands of current small quantities of perishable goods and variety. The goods capacity suits refrigerator car for transport of frozen meat and export volume of perishable goods declined in recent years, fruit volume was diverted by parcel transportation. Therefore, the mechanical refrigerator cars idle in recent years become more and more serious. To save money, hundreds of mechanical refrigerator cars were sealed standby, and ice refrigerated vehicle can not guarantee the quality of transport, and thus the utilization of these two cars are not high.

\section{The speed of railway refrigerated transportation is Slow}

Compared with highway, railway refrigerated transport is not only complicated procedures and its slow speed. Guangzhou - Beijing, for example, highway transportation is generally arrived within 60-72 hours, and the railway will take at least 120 hours. Compared to international convention photograph, there still exists a great gap, because there is half the time consumed to be sent, to be hung, to be de-compile, to be icing, and other transportation organizations. According to the data, rail transport speed is 1080-1200km / day in Europe and the United States. Thus, Beijing - Guangzhou is about 2 days to arrive.

\section{Because of Limit transportation distance, multimodal transport is difficult to achieve}

After the railway construction of "Eighth Five-Year", "Ninth Five-Year", railway mileage has increased considerably, while the existing operator network of ice refrigerated car was difficult to adapt to the needs of transport market, so that the transportation distance of perishable goods was constrained.

Since the railway has not yet created conditions for refrigerated container transport, it neither can pick up the refrigerated container shipping to the port, nor the domestic or export of refrigerated transport container cargo currently. And it causes that intermodal refrigerated rail transport in China is still not realized.

In order to ensure transport quality of the fresh perishable goods, developed countries had adopted an organization method of rail, sea and land multimodal transport. The fresh perishable goods cold chain, including production, processing, storage, transportation, and sales, had been established. In the transport process, all of the transportation adopted refrigerated trucks or refrigerated containers and coupled with EDI and other advanced information technology. It made the shipping rates of perishable 
goods refrigerated transport reached $100 \%$, the proportion in good condition of refrigerated transport closed to $100 \%$.

However, China has not yet formed a complete cold chain. Railway refrigerated transport is still waiting for the consignor, and it failed to involve in the production, transportation, sales process of perishable goods, or through close links with other transport modes to provide a full range of services to effectively develop the market for the perishable goods transport.

\section{Development countermeasures of railway refrigerated transport}

At present there are some aspects of the railway do not go with the perishable goods transport demand. It hindered the development of rail transport of perishable goods. In addition to the management system issues, there are still some transport organizations and the techniques and strategies of vehicle dispatching management and other issues. To continue the development of refrigerated railway transport, occupy a certain market share in transportation of perishable goods, the railway should to base on market characteristics, formulating appropriate development strategies, developing appropriate transport products, improving related technology and organization.

\section{Adopting information technology to reform refrigerated transport organization}

Developed countries adopted the advanced information technology when they used of refrigerated containers massively, to control of the whole process of refrigerated transport. The computer network management system like the United States, Japan, and electronic data exchange system of Europe, all played a very good role in refrigerated transport. Chinese railway transportation should also be utilizing the resources provided by management information system, to make the dynamic monitoring of refrigerated cargo of a variety of refrigerated trucks and realize priority organizations, simplified plan approval procedures of refrigerated transport. In order to meet the demand of market, " 5 the row that decide a class"(fixed time, fixed routing, fixed freight, fixed station and fixed the train number) of refrigerated transportation should be launched and the green channel should be established. It also should be based on business process of rail transport, actively establish computer management information systems and electronic data exchange system with a unified standard data.

\section{Developing the advanced refrigeration equipment Adopting information technology to reform} refrigerated transport organization

The development of refrigerated transport equipment abroad in the refrigerated transport plays a crucial role. Developed countries phased out the icing refrigerator car and mechanical refrigerator car. Since the 1980s, the average annual reefer container is increased by degrees at the speed of $15 \%$. At present machine-cooling reefer container has been widely used, and with ventilation, atmosphere, liquid nitrogen, insulation, cold plate.

\section{Carrying out multimodal transport of perishable goods}

Multimodal transport can reduce transport cost and speed flow of goods. It has the important effect to promoting economic development. The trade development made the requirements of refrigerated transport growing. Railway should break the barriers, actively develop the combined transport network of railways, highways, waterways. Meanwhile railway refrigerated freight agent should be developed. Transport agents as the stable business relations of shipper and the carrier, can improve the market competitiveness of the railway.

\section{Shortening the transit period of refrigerated transport}

The transit period of refrigerated transport is the key to ensure the quality of refrigerated transport. Rail refrigerated traffic volume flows to other modes of transport each year, in most cases is due to rail transit period is not guaranteed. Therefore, the effective management measures of refrigerated transport as increasing assessment dynamics of stopping time and transit time, strict assessment criteria of traveling time of refrigerated transport vehicles, should be increased. At the same time, each branches of railway as transportation and machines, engineering, electricity, vehicles, should improve 
the recognition of seriousness, responsibility and efficiency of the freight transportation contract, and should fulfil obligation seriously.

\section{Strengthening the cooperation with the Agricultural Product Logistics Parks}

Piecemeal of large enterprises is one of the reasons of railway refrigeration volume flowing to other modes of transport. The construction of crops logistics parks could concentrate dispersed supply, organize large-scale transport. For an example, take agricultural products of Maoming, the countryside of the fruit, in the logistics park of the planning agricultural products, the distribution of the total amount is more than 50 percent of agricultural products in Maoming City. If railway can work closely with Logistics Park, the transport of perishable goods market is very large.

\section{References}

[1] Dj.M. Maric, P.F. Meier and S.K. Estreicher: Mater. Sci. Forum Vol. $83-87$ (1992), p. 119

[2] M.A. Green: High Efficiency Silicon Solar Cells (Trans Tech Publications, Switzerland 1987).

[3] Y. Mishing, in: Diffusion Processes in Advanced Technological Materials, edtied by D. Gupta Noyes Publications/William Andrew Publising, Norwich, NY (2004), in press.

[4] G. Henkelman, G.Johannesson and H. Jónsson, in: Theoretical Methods in Condencsed Phase Chemistry, edited by S.D. Schwartz, volume 5 of Progress in Theoretical Chemistry and Physics, chapter, 10, Kluwer Academic Publishers (2000).

[5] R.J. Ong, J.T. Dawley and P.G. Clem: submitted to Journal of Materials Research (2003)

[6] P.G. Clem, M. Rodriguez, J.A. Voigt and C.S. Ashley, U.S. Patent 6,231,666. (2001)

[7] Information on http://www.weld.labs.gov.cn 